\title{
Komparasi Penyelesaian Pengaduan Nasabah Antara BPD D. I. Yogyakarta dan BPR Danagung Bakti Group
}

Rasyid Yuliansyah*, A ni Yunita**

DATA NASKAH

Masuk: 7 Nopember 2017

Diterima: 8 Mei 2017

Terbit: 1 Juni 2018

KORESPONDEN PENULIS:

*) Kejaksaan Negeri Barito Kuala. Jalan

Patmaraga No. 01 Kecamatan

Marabahan, Kab. Barito Kuala,

Provinsi Kalimantan Selatan.

Email: rasyid.yuliansyah@ gmail.com

**) Fakultas Hukum Universitas Muhammadiyah Yogyakarta. Jalan Brawijaya, Tamantirto, Kasihan, Bantul DIY.

Email: masayunita2302@gmail.com

\section{ABSTRACT}

This study is determined how the customer claims settlement system of the Regional D evelopment Bank of Yogyakarta and D anagung Bakti's Rural Bank and its Legal I mplications. This type of research is empirical juridical research which used primary data and secondary data. D ata collection method used interviews, study literature and documents. The reseach results showed that $\mathrm{C}$ ustomer Complaints settlement system in R egional D evelopment Bank of Yogyakarta and D anagung Bakti's Rural Bank accordance with PBI N umber 7/ 7/ PBI/ 2005 as amended by Regulation N umber 10/ 10/ PBI/ 2008 on settlement of C ustomer $\mathrm{C}$ omplaints although the level of implementation in the field there are still some deficiencies. The legal implications of Standart 0 perating Procedure in the Regional D evelopment Bank (BPD) of DIY is good implementation on customer complaints settlement process at Regional D evelopment Bank DIY. $O \mathrm{n}$ the other hand, the absence of Standart 0 perating Procedure in Bank Perkreditan Rakyat $D$ anagung $B$ akti is not optimal on customer complaint settlement process at D anagung Bakti Rural Bank.

K eywords: Settlement System, C ustomer Complaint, BPD DIY, BPR D anagung Bakti

\section{ABSTRAK}

Penelitian ini bertujuan untuk mengetahui bagaimana sistem penyelesaian pengaduan nasabah Bank Pembangunan Daerah Daerah Istimewa Yogyakarta dan Bank Perkreditan Rakyat Danagung Bakti serta Implikasi hukumnya. Tipe penelitian yang digunakan adalah tipe penelitian Yuridis Empiris (N on-D oktrinal) yang terdiri dari data primer dan sekunder. Teknik pengumpulan data dilakukan dengan wawancara, studi pustaka, atau dokumen. Hasil penelitian diketahui bahwa sistem penyelesaian pengaduan nasabah pada Bank Pembangunan Daerah 
Daerah Istimewa Yogyakarta telah sesuai dengan PBI Nomor 7/ 7/ PBI/ 2005 sebagaimana telah diubah dengan PBI Nomor 10/10/PBI/2008 tentang Penyelesaian Pengaduan Nasabah, meskipun dalam tataran penerapan secara teknis di lapangan masih terdapat beberapa kekurangan. Penyelesaian pengaduan nasabah di Bank Perkreditan Rakyat Danagung Bakti masih belum sesuai dengan PBI N omor 7/ 7/ PBI/ 2005 sebagaimana telah diubah dengan PBI Nomor 10/10/ $\mathrm{PBI} 2008$ tentang Penyelesaian Pengaduan Nasabah dikarenakan belum adanya Standard 0 perating Procedure (SO P). Implikasi hukum terkait sudah adanya SO P di Bank Pembangunan Daerah (BPD) DIY membuat lancar pelaksanaan proses penyelesaian Pengaduan $\mathrm{N}$ asabah di Bank BPD DIY. Sedangkan implikasi terkait tidak adanya SOP di Bank Perkreditan Rakyat Danagung Bakti menyebabkan masih kurang optimalnya proses penyelesaian pengaduan nasabah di Bank Perkreditan Rakyat D anagung Bakti.

Kata Kunci: Sistem Penyel esaian, Pengaduan Nasabah, BPD DIY, BPR Danagung Bakti.

\section{PENDAHULUAN}

Perbankan merupakan salah satu lembaga keuangan yang memberikan sumbangsih yang cukup besar terhadap pertumbuhan ekonomi suatu negara. Hal ini dikarenakan perbankan merupakan inti dari perekonomian suatu negara yang telah menjadi instrumen penting dalam memperlancar jalannya pembangunan suatu negara. Hal tersebut terlihat dari salah satu fungsinya sebagai lembaga perantara keuangan (financial intermediation) (Yunita, 2015: 157). Pihak yang membutuhkan dana selanjutnya disebut dengan nasabah dalam dunia perbankan merupakan konsumen dari pelayanan jasa perbankan. Kedudukan nasabah dalam hubungannya dengan pelayanan jasa perbankan berada pada dua posisi yang dapat bergantian sesuai dengan sisi mana mereka berada. Pada dasarnya nasabah merupakan konsumen dari pelaku usaha yang menyediakan jasa di sektor usaha perbankan (Djumhana, 2003:282).

Fungsi lembaga perbankan sebagai perantara pihak-pihak yang memiliki kelebihan dana dengan pihak-pihak yang memerlukan dana membawa konsekuensi pada timbulnya interaksi yang intensif antara bank sebagai pelaku usaha dengan nasabah sebagai konsumen pengguna jasa perbankan. Interaksi yang demikian intensif antara bank dengan nasabah bukan suatu hal yang tidak mungkin apabila terjadi friksi yang apabila tidak segera diselesaikan dapat berubah menjadi sengketa antara nasabah dengan bank. Dari berbagai pengalaman yang ada maka timbulnya friksi tersebut terutama disebabkan oleh empat hal, yaitu (Tim LPKNI Jatim, 2014):

1. Informasi yang kurang memadai mengenai karakteristik produk atau jasa yang ditawarkan bank;

2. Pemahaman nasabah terhadap aktivitas dan produk atau jasa perbankan yang masih kurang;

3. Ketimpangan hubungan antara nasabah dengan bank, khususnya bagi nasabah peminjam dana; dan

4. Tidak ada saluran yang memadai untuk memfasilitasi penyelesaian awal friksi yang terjadi antara nasabah dengan bank.

Peraturan Bank Indonesia Nomor 7/6/PBI/2005 tentang Transparansi Informasi Produk Bank dan Penggunaan Data Pribadi Nasabah dan Peraturan Bank Indonesia Nomor 7/7/ PBI/2005 tentang Penyelesaian Pengaduan Nasabah yang menjadi bagian dari Paket Kebijakan Perbankan Januari 2005 dan Peraturan Bank Indonesia Nomor 8/5/PBI/2006 tentang M ediasi Perbankan sebagai bagian dari Paket Kebijakan Perbankan Januari 2006. Hal tersebut merupakan realisasi dari upaya Bank Indonesia untuk menyelaraskan kegiatan usaha perbankan dengan amanat Undang-Undang Perlindungan Konsumen yang mewajibkan adanya kesetaraan hubungan antara pelaku usaha (bank) dengan konsumen (nasabah) (Priliasari, 2008).

Pasca terbentuknya Otoritas Jasa Keuangan (OJK), jumlah pengaduan nasabah perbankan tahun 2014 per 10 Maret 2014 mencapai 639 pengaduan atau 43,2\% terhadap total pengaduan nasabah indsutri keuangan sebanyak 1.479 pengaduan (http://keuangan.kontan.co.id/news/adalembaga-mediasi-bank-alternatif, diaksespada 21 April 2014 jam 19.30 WIB). Pada tahun 2013 jumlah pengaduan nasabah perbankan melalui Otoritas Jasa Keuangan (OJK) mencapai 52 aduan dari total aduan sebanyak 1.375 aduan (Kusuma, 2014).

Sebelum Peraturan Bank Indonesia Nomor 7/7/PBI/2005 tentang Penyelesaian Pengaduan Nasabah maupun 
perubahannya dalam Peraturan Bank Indonesia Nomor 10/ 10/PBI/2008 tentang Penyelesaian Pengaduan Nasabah bahwa tiap bank sudah mempunyai upaya untuk menyelesaikan tiap pengaduan nasabah yang masuk. Hanya saja proses penyelesaian pengaduan nasabah tersebut belum terstandarisasi dan berbeda-beda dari satu bank dengan bank lainnya. Dengan dikeluarkannya Peraturan Bank Indonesia Nomor 7/7/PBI/2005 tentang Penyelesaian Pengaduan Nasabah maupun perubahannya dalam Peraturan Bank Indonesia Nomor 10/10/PBI/2008 tentang Penyelesaian Pengaduan Nasabah diharapkan proses penyelesaian pengaduan nasabah bisa terstandarisasi.

Hal yang menarik adalah mengenai pelaporan dari hasil penyelesaian pengaduan nasabah yang dilaporkan secara triwulanan kepada Otoritas Jasa Keuangan (dahulu Bank Indonesia) pada bulan M aret, Juni, September, dan Desember.M engingat adanya perbedaan antara Bank umum dan Bank Perkreditan Rakyat.Bank umum melaporkannya secara on-line sesuai dengan sistem Laporan Kantor Pusat Bank Umum (LKPBU) sedangkan Bank Perkreditan Rakyat masih menggunakan sistem manual. Tentunya sedikit banyak hal ini akan berpengaruh tehadap para pihak yang terkait baik terhadap Bank Umum maupun Bank Perkreditan Rakyat. Perbedaan pelaporan tersebut menjadi salah satu alasan pentingnya mengkaji perbandingan antara Bank Pembangunan Daerah di Daerah Istimewa Yogyakarta (BPD DIY) sebagai sebuah bank umum dan Bank Perkreditan Rakyat Danagung Bakti sebagai sebuah Bank Perkreditan Rakyat (BPR Danagung Bakti).

Selain Perbedaan sistem pelaporan kepada OtoritasJasa Keuangan terdapat alasan yang lebih kuat lagi yang menyebabkan pentingnya pengkajian antara ialah kedua Bank tersebut sebagai sebuah bank yang memiliki perbedaan segmentasi. Bank Umum lebih berorientasi pada masyarakat kelas menengah keatas terutama masyarakat yang tinggal di daerah perkotaan, sedangkan Bank Perkreditan Rakyat lebih berorientasi untuk melayani usaha-usaha kecil dan masyarakat di daerah pedesaan. Perbedaan variasi jenis pengaduan antara Bank Umum dengan Bank Perkreditan Rakyat tentu saja juga berimplikasi pada variasi cara penyelesaian pengaduan nasabah, variasi jangka waktu penyelesaian pengaduan nasabah, serta variasi hasil penyelesaian pengaduan nasabah diantara kedua bank tersebut.

BPD DIY dan BPR Danagung Bakti sebagai bank yang cukup tua keberadaannya di Daerah Istimewa Yogyakarta dan sekaligus sebagai motor penggerak pertumbuhan perkonomian. Kedua bank tersebut telah banyak memiliki pengalaman dalam masalah pelayanan nasabah termasuk dalam penyelesaian pengaduan nasabah, baik pra maupun pasca dikeluarkannya PBI Nomor 7/7/2005 jo.PBI Nomor 10/10/2008 tentang Penyelesaian Pengaduan Nasaba (Bank BPD DIY, 2014).

\section{RUMUSAN MASALAH}

1. Bagaimana sistem penyelesaian pengaduan nasabah BPD DIY dan BPR Danagung Bakti?

2. Apa Implikasi yang terjadi dari sistem penyelesaian pengaduan nasabah BPD DIY dan BPR Danagung Bakti?

\section{METODE PENELITIAN}

Jenis penelitian ini adalah penelitian yuridis empiris (nondoktrinal). Penelitian ini menggunakan konsep hukum sebagai manifestasi makna-makna simbolik perilaku pelaku sosial yang tampak dalam interaksi mereka (Setiono, 2010:20-21). Lokasi penelitian dilakukan di kantor BPD DIY dan kantor BPR Danagung Group. Bahan hukum yang digunakan adalah bahan hukum sekunder dan bahan hukum primer yang merupakan sumber utama. Teknik pengumpulan data yang digunakan untuk memperoleh sumber data primer adalah melalui wawancara mendalam (Indepth Interview) secara langsung dengan pegawai BPD DIY dan BPR Danagung Group. Serta untuk mendukung keakuratan data primer, maka diperlukan data sekunder atau studi pustaka yang berupa dokumen-dokumen bank, peraturan perundangundangan dan buku-buku yang terkait dengan hukum perbankan (Soekanto, 2006:21). Adapun mengenai teknik analisis data yang digunakan dalam penelitian ini adalah teknik analisis model interaktif (interactive model of analysis). 


\section{HASIL PENELITIAN DAN ANALISIS}

\section{A. Sistem Penyelesaian Pengaduan Nasabah BPD DIY dan BPR Danagung Bakti}

\section{Sistem Penyelesaian Pengaduan Nasabah BPD}

DIY.

Sistem Penyelesaian pengaduan nasabah BPD DIY dapat diajukan secara lisan dan tertulis. Adapun sistem penyelesaian dapat dilakukan sebagai berikut:

1) Prosedur penerimaan pengaduan diajukan secara lisan ialah sebagai berikut:

a) Pengaduan dilakukan tanpa tatap muka hanya dapat diajukan secara langsung oleh nasabah yang bersangkutan melalui telepon.

b) Pengaduan dilakukan secara tatap muka dapat diajukan oleh nasabah dan atau perwakilan nasabah.

c) Petugas penerima pengaduan meminta informasi dari nasabah terkait permasalahannya.

d) Apabila pengaduan diajukan oleh perwakilan nasabah maka selain informasi diatas juga meminta fotokopi bukti identitas perwakilan nasabah dan surat kuasa khusus dari nasabah kepada perwakilan nasabah.

e) Data informasi pengaduan secara lisan tanpa tatap muka ditulis dalam formulir FPN-01.A dan dicatat dalam register penerimaan pengaduan selanjutnya menyampaikan pada nasabah.

f) Data informasi pengaduan secara lisan dengan tatap muka ditulis dalam formulir FPN-01.B dan dicatat dalam register penerimaan pengaduan selanjutnya menyampaikan kepada nasabah berupa tembusan formulir FPN-01.B yang telah diisi lengkap dan penjelasan singkat mengenai kebijakan dan prosedur yang akan ditempuh bank dalam menyelesaikan pengaduan..

g) Apabila jangka waktu yang diperlukan untuk menyelesaikan pengaduan secara lisan diperkirakan akan melebihi dua hari kerja maka petugas penerima pengaduan dan atau petugas penanganan dan penyelesaian pengaduan meminta nasabah untuk mengajukan pengaduan secara tertulis pada saat nasabah mengajukan pengaduan secara lisan.

2) Prosedur penerimaan diajukan secara tertulis diatur sebagai berikut:

a) Pengaduan dilakukan secara dapat diajukan oleh nasabah dan atau perwakilan nasabah. Nasabah menggunakan formulir yang disediakan (FPN-01.B) yang memuat data nasabah dan uraian pengaduan. Data nasabah antara lain nama nasabah, tempat dan tanggal lahir nasabah, alamat dan nomor telepon nasabah, jenis dan Nomor Tanda Pengenal Identitas Nasabah. Uraian pengaduan mengenai jenis pengaduan, transaksi bank yang diadukan, nomor rekening dan atau Bilyet Transaksi bank yang diadukan nasabah, kategori permasalahan yang diadukan nasabah dan penjelasan singkat uraian pengaduan.

b) Pengajuan pengaduan tertulis dilampiri dengan dokumen fotokopi bukti identitas nasabah, bukti transfer, statement of account; dan atau dokumen pendukung lainnya yang dimiliki dan atau dikuasai oleh nasabah.

\section{Prosedur Penanganan dan Penyelesaian Pengaduan Berdasarkan Cara Penyampaian dan Obyek Pengaduan}

1) Prosedur penanganan dan penyelesaian pengaduan secara lisan terhadap produk bank diatur sebagai berikut:

a) Petugas penanganan dan penyelesaian bekerja sama dengan unit kerja yang terkait dengan permasalahan yang diadukan melakukan koordinasi untuk menyelesaikan pengaduan;

b) Proses penanganan dan penyelesaian pengaduan diadministrasikan dalam register penganganan dan penyelesaian pengaduan nasabah;

c) Bank menyampaikan hasil penyelesaian pengaduan secara tertulis kepada nasabah dan atau perwakilan nasabah dengan menggunakan format surat pemberitahuan hasil penyelesaian pengaduan dalam waktu 2 (dua) hari kerja sejak diterimanya pengaduan;

d) Dalam hal pengaduan nasabah terkait dengan transaksi keuangan yang melibatkan Pejabat Bank dan atau kewenangannya mengalami permasalahan, maka penanganan dan penyelesaian pengaduan diselesaikan oleh Pejabat dan atau kantor bank yang lebih tinggi tingkatannya. 
2) Prosedur Penerimaan Pengaduan Yang Diajukan Secara Tertulis Terhadap Produk Bank.

Prosedur penanganan dan penyelesaian pengaduan secara tertulisterhadap produk yang diterbitkan bank diatur sebagai berikut:

a) Petugas Penanganan dan Penyelesaian Pengaduan bekerja sama dengan unit kerja yang terkait dengan permasalahan yang diadukan.

b) Proses penanganan dan penyelesaian pengaduan diadministrasikan dalam register penanganan dan penyelesaian pengaduan nasabah.

c) Perpanjangan jangka waktu penyelesaian pengaduan harus diberitahukan terlebih dahulu kepada nasabah dan atau perwakilan sebelum batas waktu 20 (dua puluh) hari.

d) Petugas Penanganan dan Penyelesaian Pengaduan menyampaikan hasil penyelesaian pengaduan secara tertulis kepada nasabah dan atau perwakilan nasabah.

e) Dalam hal pengaduan nasabah terkait dengan transaksi keuangan yang melibatkan pejabat bank dan atau kewenagannya mengalami permasalahan, maka penanganan dan penyelesaian pengaduan diselesaikan oleh pejabat dan/atau kantor bank yang lebih tinggi tingkatannya.

f) Petugas Penanganan dan Penyelesaian Pengaduan menyusun ringkasan penyelesaian pengaduan tertulis dalam register penanganan dan penyelesaian pengaduan nasabah yang memuat data dan informasi singkat penerimaan, penanganan, dan hasil penyelesaian pengaduan.

\section{Pelaporan}

1) Pengelolaan pelaporan

a) Secara periodik setiap kantor membuat laporan penanganan dan penyelesaian pengaduan nasabah yang disampaikan kepada kantor pusat up.Divisi perencanaan dan pengembangan melaui kantor cabang.

b) Laporan triwulanan penanganan dan penyelesaian pengaduan nasabah disampaikan secara triwulanan yaitu untuk periode pelaporan yang berakhir pada bulan Maret, Juni, September dan Desember.

c) Batas waktu penyampaian laporan yang disampaikan oleh kantor cabang paling lambat tanggal 10 pada bulan sesudah bulan laporan atau disampaikan hari sebelumnya apabila tanggal 10 jatuh hari libur.

d) Divisi perencanaan dan pengembangan menyampaikan laporan triwulanan penanganan dan penyelesaian pengaduan nasabah kepada kantor Bank Indonesia Cabang Yogyakarta JI P.Senopati Nomor 4-6, Yogyakarta dengan tembusan ditujukan kepada:

1) Unit khusus investigasi perbankan di Jl, $\mathrm{MH}$ Thamrin Nomor 2, Jakarta

2) Satuan Pengawasan Intern

3) Divisi Manajemen Risiko dan Kepatuhan

Dalam pandangan Dahrendorf, konflik dan pertentangan merupakan hal-hal yang positif. Konflik diperlukan untuk menyelenggarakan perubahan dalam masyarakat. Namun syarat untuk itu ialah bahwa konflik-konflik ini harus dibudayakan dan membudaya. Untuk mendapatkan haknya, orang-orang tidak boleh menggunakan paksaan dan kekerasan apalagi saling membunuh, melainkan harus dibentukinstitusi-institusi khususuntuk penyelesaian konflikkonflik tersebut (Rijkschroff, 2001:142).

Institusi khusus sesuai yang dimaksud oleh Dahrendorf dalam dunia perbankan terdapat beberapa; Mediasi Perbankan oleh Bank Indonesia, Lembaga Penyelesaian Pengaduan Nasabah, Arbitrase, \& Jalur Litigasi yang melibatkan pengadilan. Bila demikian maka bisa dikatakan bahwa penyelesaian pengaduan nasabah yang saat ini penulis bahas merupakan salah satu wujud dari institusi khusus yang bermanfaat dalam memberikan perubahan ke arah positif di dalam masyarakat. Hal ini juga sesuai dengan pernyataan Dahrendorf yang menyatakan bahwa melalui konflik-konflik yang memakai aturan, pada gilirannya harus dilihat sebagai motor kreatif penggerak kemajuan (Rijkschroff, 2001:142).

Dilihat dari teori penyelesaian sengketa, maka yang paling tepat jika dikaitkan dengan sistem penyelesaian pengaduan nasabah di bank BPD DIY adalah teori negosiasi prinsip dari Simon Fisher, dkk. yang menyatakan bahwa penyebab terjadinya sengketa adalah dikarenakan oleh posisi-posisi yang tidak selaras dan perbedaan pandangan tentang sengketa oleh pihak-pihak yang mengalami sengketa.

Jika dilihat menggunakan teori negosiasi prinsip, maka adanya posisi yang tidak selarastersebut yaitu antara nasabah 
yang memiliki kepentingan agar pengaduannya terselesaikan dengan pihak bank yang merasa berada di atas angin karena merasa penyelesaian pengaduan nasabah darinya sangat dibutuhkan oleh nasabah. Dalam hal perbedaan pandangan tentang sengketa bisa dilihat ketika nasabah memandang kepentingannya atas pengaduan yang diajukan sebagai sesuatu yang harus diselesaikan sesuai keinginannya dan secepat mungkin sedangkan pihak bank memandang pengaduan yang diajukan oleh nasabah adalah sesuatu yang harus diselesaikan namun tidak boleh mengorbankan kepentingan pihak bank, baik kepentingan langsung maupun tidak langsung.

Penulis mewawancarai salah seorang nasabah yang melakukan pengaduan atas kartu ATM nya yang tidak bisa dipakai, pengaduan ini dilakukan secara lisan dan dapat diselesaikan oleh bank BPD DIY dengan tidak terlalu lama yaitu sekitar kurang lebih 1 jam. Namun disini, terdapat contoh dimana terdapat cara pandang penyelesaian yang berbeda antara pihak bank dengan pihak nasabah, hal ini didasari bahwa ternyata kartu ATM milik nasabah bersangkutan yang tidak dapat dipergunakan adalah dikarenakan terblokir. Untuk menyelesaikannya nasabah diharuskan membuat PIN baru setelah blokirnya dibuka oleh pihak bank dan ini dikenakan biaya Rp5.000,00 (lima ribu rupiah). Di sisi lain nasabah merasa bahwa penyelesaian pengaduannya ini seharusnya tidak memerlukan biaya (gratis) meskipun pada akhirnya nasabah yang saya wawancarai tetap membayar biaya sebesar Rp5.000,00 (lima ribu rupiah) yang mana ini menunjukkan pengaruh dari posisi yang tidak seimbang antara pihak bank dengan pihak nasabah ditinjau dari teori Simon Fisher. Pihak bank merasa posisi tawarnya lebih tinggi dikarenakan pihak banklah yang merasa bisa menyelesaikan permasalahan yang dialami nasabah bersangkutan.

\section{B. Sistem Penyelesaian Pengaduan Nasabah BPR D anagung Bakti}

Dalam wawancara dengan Bapak Tedy Alamsyah selaku Direktur Utama BPR Danagung Bakti, didapatkan keterangan bahwa pengaduan oleh nasabah pada BPR Danagung Bakti dapat dilakukan baik secara lisan maupun tertulis. Namun, pada umumnya, nasabah BPR Danagung Bakti sangatjarang yang mengajukan pengaduan secara tertulis dan lebih banyak yang melakukan pengaduan secara lisan melalui Customer Service Bank BPR Danagung Bakti.

Rata-rata pengaduan ialah berkenaan dengan ATM dan permasalahan kredit dengan rata-rata jangka waktu penyelesaian pengaduan (dari diterimanya pengaduan hingga terselesaikannya pengaduan) ialah tidak lebih dari satu bulan. Hal ini dikarenakan sederhananya masalah yang dilaporkan oleh nasabah. M enurut hasil wawancara dengan salah seorang nasabah, yang mengadukan permasalahan terkait dengan kartu ATM yang tidak dapat difungsikan. Pihak BPR Danagung Bakti setelah melakukan pengecheckan, didapati bahwa pin dari kartu ATM tersebut telah terblokir sehingga diberikanlah pin ATM baru kepada nasabah bersangkutan. Dalam proses tersebut, jangka waktu yang diperlukan oleh Bank BPR Danagung Bakti hanyalah kurang lebih $1 \mathrm{Jam}$.

Tidak seperti pada Bank BPD DIY yang menggunakan beberapa jenis register untuk pencatatan pengaduannya, pada BPR Danagung Bakti hanya menggunakan satu jenis register untuk pencatatan pengaduan nasabah. Berdasarkan hasil wawancara dengan Dra. Sri Mulyani selaku Direktur Operasional Bank BPR Danagung Bakti, didapat jawaban bahwa penggunaan satu register dikarenakan kuantitas pengaduan nasabah yang tidak terlalu banyak sehingga dirasa cukup dengan menggunakan satu register, baik untuk pengaduan lisan maupu pengaduan tertulis. Perbedaan hanyalah adanya catatan tambahan pada kolom keterangan guna membedakan apakah pengaduan tersebut disampaikan secara lisan ataukah secara tertulis.

Standart Operating Procedur (SOP) Penyelesaian Pengaduan Nasabah pada BPR Danagung Bakti belumlah dibuat secara tertulis, akan tetapi menurut Ibu Dra. Sri Mulyani, SOP Penyelesaian Pengaduan Nasabah pada dasarnya mengacu pada PBI Nomor 7/7/PBI/2005 tentang Penyelesaian Pengaduan Nasabah sebagaimana telah diubah dengan PBI Nomor 10/10/PBI/2008. Mengenai pelaporan kepada Bank Indonesia yang sekarang telah diambil alih oleh OJK (Otoritas Jasa Keuangan) maka khusus Bank Perkreditan Rakyat adalah masih dilakukan secara manual setiap tiga bulan sekali.

Dalam pandangan Dahrendorf, konflik dan pertentangan 
merupakan hal-hal yang positif. Konflik diperlukan untuk menyelenggarakan perubahan dalam masyarakat. Namun syarat untuk itu ialah bahwa konflik-konflik ini harus dibudayakan dan membudaya. Untuk mendapatkan haknya, orang-orang tidak boleh menggunakan paksaan dan kekerasan apalagi saling membunuh, melainkan harus dibentuk institusi-institusi khususuntuk penyelesaian konflikkonflik tersebut (Rijkschroff, 2001:142). Institusi khusus sesuai yang dimaksud oleh Dahrendorf dalam dunia perbankan terdapat beberapa alternatif, yaitu: Mediasi Perbankan oleh Bank Indonesia, Lembaga Penyelesaian Pengaduan Nasabah, Arbitrase, \& Jalur Litigasi yang melibatkan pengadilan.

Pada dasarnya Bank Perkreditan Rakyat Danagung Bakti belum sepenuhnya mempunyai sistem Penyelesaian Pengaduan Nasabah yang terstandarisasi dan benar-benar sesuai dengan PBI Nomor 7/7/PBI/2005 tentang Penyelesaian Pengaduan Nasabah sebagaimana telah diubah dengan PBI Nomor 10/10/PBI/2008. Namun, usaha untuk bisa sesuai terhadap PBI Nomor 7/7/PBI/2005 tentang Penyelesaian Pengaduan Nasabah sebagaimana telah diubah dengan PBI Nomor 10/10/PBI/2008 telah terlihat.

Dilihat dari teori penyelesaian sengketa, maka yang paling tepat jika dikaitkan dengan sistem penyelesaian pengaduan nasabah di Bank Perkreditan Rakyat Danagung Bakti adalah teori negosiasi prinsip dari Simon Fisher yang menyatakan bahwa penyebab terjadinya sengketa adalah dikarenakan oleh posisi-posisi yang tidak selaras dan perbedaan pandangan tentang sengketa oleh pihak-pihak yang mengalami sengketa.

Pada BPR Danagung Bakti mengenai ketidakseimbangan posisi antara bank dengan nasabah bukan hanya terblokir kartu ATM nya melainkan kartu ATM nya tertelan oleh mesin ATM sehingga nasabah bersangkutan diharuskan membayar biaya penerbitan kartu baru senilai Rp25.000,00 (dua puluh lima ribu rupiah) dan diharuskan menunggu hingga satu hari untuk mengambil kartu ATM yang baru,dalam hal ini nasabah bersangkutan mengambil kartu ATM nya yang baru pada keesokan harinya. Kondisi ini merupakan salah satu contoh nyata dari teori negosiasi prinsip dari Simon Fisher yang pada intinya menyatakan adanya ketidakseimbangan posisi dari para pihak dan perbedaan pandangan tentang sengketa oleh pihak-pihak yang mengalami sengketa.

Selain teori penyelesaian sengketa, jika dilihat dari tujuh cara penyelesaian sengketa menurut Laura Nader dan Harry F. Todd Jr, maka cara penyelesaian pengaduan nasabah pada Bank Perkreditan Rakyat Danagung Bakti adalah termasuk cara keempat yaitu Perundingan (negotiation). Dua pihak yang berhadapan merupakan pengambil keputusan. Pemecahan atas masalah yang dihadapi dilakukan oleh mereka berdua. M ereka sepakat tanpa adanya pihak ketiga yang mencampurinya. Kedua belah pihak berupaya untuk saling meyakinkan.

\section{Implikasi hukum terhadap sistem penyelesaian pengaduan nasabah BPD DIY dan B PR D anagung B akti}

a. Implikasi hukum terhadap sistem penyelesaian pengaduan nasabah Bank Pembangunan Daerah Daerah Istimewa Yogyakarta

Implikasi Hukum yang terjadi dengan adanya sistem penyelesaian pengaduan nasabah pada BPD DIY seperti yang tersebut di atas adalah nasabah menjadi semakin percaya diri dalam melakukan suatu transaksi perbankan, serta mengurangi rasa ragu-ragu nasabah dalam melakukan suatu transaksi perbankan. Hal ini sangat berbeda dengan ketika sistem penyelesaian pengaduan nasabah belum terstandarisasi oleh PBI Nomor 7/7/PBI/2005 sebagaimana telah diubah dengan PBI Nomor 10/10/PBI/2008 tentang Penyelesaian Pengaduan Nasabah. Sebaliknya bagi Bank BPD DIY, adanya sistem penyelesaian pengaduan nasabah yang terstandarisasi mengakibatkan bank semakin berhati-hati dalam melaksanakan transaksi perbankan dan lebih menekankan perlindungan terhadap hak dan kepentingan nasabah.

Bagi lembaga pengawas seperti Otoritas Jasa Keuangan (OJK), adanya PBI Nomor 7/7/PBI/2005 sebagaimana telah diubah dengan PBI Nomor 10/10/PBI/2008 tentang Penyelesaian Pengaduan Nasabah sebagai sebuah sistem penyelesaian pengaduan nasabah di Indonesia telah memberikan suatu standarisasi dalam sistem pengawasan terhadap upaya penyelesaian pengaduan nasabah yang dilakukan oleh bank-bank yang ada di Indonesia. 
Adanya pembedaan sistem penyelesaian pengaduan nasabah antara yang tertulis dan lisan juga menyebabkan implikasi khusus berupa perbedaan jangka waktu penyelesaian pengaduan. Implikasi lainnya menurut Bapak W isnu dari Divisi Trisuri adalah berupa pemilahan antara complain nasabah yang tergolong masalah ringan dan masalah berat. Masalah ringan pada dasarnya adalah masalah yang dapat diselesaikan dalam jangka waktu tidak lebih dari 2 (dua) hari kerja, sedangkan masalah berat adalah masalah yang butuh penyelesaian lebih dari 2 (dua) hari kerja dan oleh karena itu wajib pengaduan tersebut dilakukan secara tertulis.

b. Implikasi hukum terhadap sistem penyelesaian pengaduan nasabah BPR Danagung Bakti

Didalam penerapan PBI Nomor 7/7/PBI/2005 sebagaimana telah diubah dengan PBI Nomor 10/10/PBI/ 2008tentang Penyelesaian Pengaduan Nasabah. Pada Bank Perkreditan Rakyat Danagung Bakti mempunyai beberapa perbedaan dengan penerapan yang dilakukan pada BPD DIY. Perbedaan tersebut adalah:

1) Pada BPD DIY, Standart Operating Procedure (SOP) yang didasarkan pada penerapan PBI Nomor 7/7/PBI/2005 sebagaimana telah diubah dengan PBI Nomor 10/10/ PBI/2008 tentang Penyelesaian Pengaduan Nasabah telah dibuat dan diterapkan, pada BPR Danagung Bakti, belum ada Standart Operating Procedure (SOP) yang digunakan khusus untk penyelesaian pengaduan nasabah.

2) Pada BPD DIY, telah dipisahkan register pengaduan tertulis dan register pengaduan secara lisan. Sedangkan pada BPR Danagung Bakti, register pengaduan baik yang secara lisan maupun yang tertulis masih digabung.

3) Pada BPD DIY, sistem pelaporan kepada Bank Indonesia (sekarang telah beralih ke Otoritas Jasa Keuangan) sudah bersifat On-Line sedangkan pada Bank Perkreditan Rakyat Danagung Bakti pelaporan tersebut masih bersifat manual. Oleh karena adanya perbedaan penerapan system penyelesaian pengaduan nasabah yang bersumber pada PBI Nomor 7/7/PBI/2005 sebagaimana telah diubah dengan PBI Nomor 10/10/PBI/2008 tentang Penyelesaian Pengaduan Nasabah, antara BPD DIY dengan BPR
Danagung Bakti, maka implikasi hukum yang dihasilkan pun sedikit berbeda.

Belum adanya Standart Operating Procedure (SOP) membuat BPR Danagung Bakti belum memberikan kejelasan sistem penyelesaian pengaduan nasabah sehingga membuat upaya penyelesaian pengaduan nasabah seolah-olah asal selesai. Bagi nasabah belum adanya Standart Operating Procedure (SOP) membuat perlindungan terhadap kepentingan nasabah menjadi belum optimal. Dengan masih disatukannya register atas pengaduan baik yang tertulis maupun lisan maka berimplikasi pada kurang baiknya pengadministrasian jenis-jenis pengaduan sesuai dengan tingkatan sukar atau mudahnya penyelesaian pengaduan.Bagi nasabah send iri dengan masih disatukannya register atas pengaduan baik yang tertulis maupun lisan tidaklah mempunyai implikasi langsung, namun ada juga implikasi yang bisa saja timbul seperti semakin lamanya proses penyelesaian pengaduan dikarenakan user dari register penyelesaian pengaduan lebih lama dalam proses meregister pengaduan nasabah.

Implikasi dari sistem pelaporan kepada Otoritas Jasa Keuangan yang masih manual (belum On-Line) adalah menyebabkan Otoritas Jasa Keuangan menerima pelaporan proses penyelesaian pengaduan nasabah dari BPR dan khususnya BPR Danagung Bakti adalah kurang cepat dan kurang up to date karena harus menunggu tiap tiga bulan sekali. Sistem pelaporan kepada Otoritas Jasa Keuangan yang masih manual (belum On-Line) bagi BPR Danagung Bakti adalah menyebabkan kurang praktis dan efisien dalam menyajikan pelaporan kepada Otoritas Jasa Keuangan.

\section{KESIMPULAN}

Berdasarkan hasil penelitian dan pembahasan maka untuk rumusan masalah yang pertama dapat disimpulkan bahwa terdapat beberapa persamaan sekaligus perbedaan diantara sistem penyelesaian pengaduan nasabah pada BPD DIY dengan BPRDanagung Bakti. Persamaan diantara dua sistem penyelesaian pengaduan nasabah tersebut adalah dimana sistem penyelesaian pengaduan nasabah pada BPD DIY dan BPR Danagung Bakti adalah sama-sama bersumber dari PBI Nomor 10/10/PBI/2008 tentang Penyelesaian Pengaduan Nasabah. 
Sistem penyelesaian pengaduan nasabah tersebut pada BPD DIY mengenai Standart Operating Procedure (SOP) yang didasarkan pada PBI Nomor 10/10/PBI/2008 tentang Penyelesaian Pengaduan Nasabah telah dibuat dan diterapkan akan tetapi pada BPRDanagung Bakti belum ada Standart Operating Procedure (SOP) yang digunakan khusus untuk penyelesaian pengaduan nasabah. Perbedaan lain pada BPD DIY telah dipisahkan register pengaduan tertulis dan register pengaduan secara lisan, sedangkan register pengaduan baik yang secara lisan maupun yang tertulis pada BPR Danagung Bakti masih digabung. Sistem pelaporan BPD DIY yang dilaporkan kepada Bank Indonesia (sekarang telah beralih ke Otoritas Jasa Keuangan) sudah bersifat On-Line sedangkan pada BPR Danagung Bakti pelaporan tersebut masih bersifat manual.

Implikasi hukum terkait sudah adanya SOP di BPD DIY mengakibatkan lancarnya pelaksanaan proses penyelesaian Pengaduan Nasabah. Adanya satu atau dua permasalahan merupakan sesuatu hal yang wajar apalagi permasalahan tersebut terkait dengan hal teknis dan bukan karena disebabkan tidak terdapatnya SOP sedangkan implikasi terkait tidak adanya SOP di BPR Danagung Bakti menyebabkan masih kurang optimalnya proses penyelesaian pengaduan nasabah di BPR Danagung Bakti. Hal ini dapat dilihat dari masih bervariasinya jangka waktu penyelesaian pengaduan Nasabah di BPR Danagung Bakti.

\section{Saran}

Saran yang dapat diberikan dalam penelitian ini ialah pertama, Bank BPR Danagung Bakti hendaknya membuat Standart Operating Procedure (SOP) yang tertulis mengenai sistem penyelesaian pengaduan nasabah sehingga lebih bisa memberikan kepastian hukum kepada pegawai BPR Danagung Bakti selaku user maupun kepada nasabah. Kedua, Bank BPD DIY agar hendaknya mengurangi biaya yang tidak terlalu urgent yang dibebankan kepada nasabah selama proses penyelesaian pengaduan nasabah. Seandainya biaya itu memang benar-benar harus dibebankan kepada nasabah, hendaknya bank memberikan penjelasan secara komprehensif dan jelas mengenai alasan timbulnya biaya yang harus ditanggung oleh nasabah tersebut.

\section{DAFTAR PUSTAKA}

Anonim, Sejarah Singkat Bank BPD DIY pada http:/ / www.bpddiy.co.id/index. sejarah diakses pada 21 A pril 2014, jam 19.30 W IB.

Djumhana, M uhammad., 2003, H ukum Perbankan di Indonesia, Bandung: Citra A ditya Bakti.

Kusuma, D ewi Rachmat, 0 JK Terima 889 Pengaduan dari M asyarakat Sepanjang 2013 pada http:/ / finance. detik.com/ read/ 2014/ 02/ 06/ 111243/ 2488889/ 5/ ojk-terima-889-pengaduan-dari-masyarakatsepanjang-2013, diaksespada 21 A pril 2014, jam 19.30 WIB.

Priliasari, Erna., 2008, “M ediasi Perbankan Sebagai W ujud Perlindungan Terhadap Nasabah Bank", Jurnal L egislasi Indonesia, Vol. 5, N o.2.

Rijkschroff, B.R. 2001, Sosiologi H ukum, C.V. M andar Maju, Bandung.

Setiono, 2010, Pemahaman Terhadap M etodologi Penelitian H ukum, Program Studi IImu H ukum Pascasarjana U N S Surakarta.

Soekanto, Soerjono., 2006, Pengantar Penelitian H ukum, Jakarta: Penerbit UI.

Tim LPKN I Jatim, Fungsi Lembaga Perbankan, terdapat dalam http:/ / Ipkni-jatim. blogspot.com/ 2013/ 01/ fungsilembaga-perbankan html,diakses pada 21 A pril 2014, jam 19 W IB.

U sman, Rachmadi., 2011, Penyelesaian Pengaduan Nasabah dan M ediasi Perbankan, Bandung: $M$ andar M aju.

Yunita, Ani, 2015, Kajian A kad Pembiayaan Murabahah Terhadap Penerapan Prinsip Syariah Pada Bank Syariah di Indonesia, Jurnal M edia H ukum, Vol.22, N o.1. 